\title{
PODATEK DOCHODOWY W ROLNICTWIE A KSIĘGI RACHUNKOWE - WIDMO ZMIAN DLA POLSKIEGO ROLNIKA
}

\section{Wstęp}

Od kilku lat w prasie oraz na portalach branżowych pojawiają się artykuły na temat planów wprowadzenia podatku dochodowego dla rolników. W roku 2011 premier Donald Tusk w swoim expose zapowiedział, że rolnicy będą prowadzić od roku 2013 rachunkowość. Przyczyną takiej decyzji jest uznanie rolnictwa $\mathrm{z}$ formę działalności gospodarczej. Planuje się objęcie zmianami największych gospodarstw i sukcesywne obejmowanie mniejszych.

Czy jest to słuszna droga dla polskiej wsi? Usystematyzowanie pewnych danych finansowych może być dla rolników korzystne. Ważne jest, jakie rozwiązania zostaną wprowadzone i w jakim tempie. Istotne jest również konsekwentne realizowanie tych zmian. Problemem polskiej wsi od lat jest brak konsekwencji przy wdrażaniu jakichkolwiek zmian przez kolejne rządy.

\section{Specyfika sektora rolnego}

Zanim zacznie się analizować zagadnienia dotyczące rolnictwa, warto zwrócić uwagę, na czym polega specyfika tego sektora. $Z$ punktu widzenia ekonomii gospodarowanie w przedsiębiorstwie rolnym polega na łączeniu takich czynników, jak ziemia, kapitał i praca w celu uzyskania specyficznych produktów, którymi są rośliny i zwierzęta. Istotnym czynnikiem jest również organizacja. Produkcja rolna jest zupełnie inna od przemysłowej, ponieważ wymienione czynniki produkcji mogą być kontrolowane przez człowieka, jednak sam efekt produkcji rolnej zależny jest również od klimatu i warunków atmosferycznych ${ }^{1}$.

Rolnictwo jest również sektorem gospodarki, w który od zawsze ingeruje państwo. Zmianom ulega sposób regulacji klasycznych czynników produkcji. Regulacje te mają charakter prawny i dotyczą np. obrotu ziemią, dzierżawy itd. Prawo kontroluje również poszczególne branże produkcji rolnej, jak np. ograniczenia $\mathrm{w}$ branży cukrowniczej czy też spirytusowej. W chwili obecnej na poziom regulacji decydujący wpływ ma Unia Europejska.

\footnotetext{
${ }^{*}$ Doktorant, Wydział Zarządzania, UŁ.

${ }^{1}$ P. Czechowski, M. Korzycka-Iwanow, S. Prutis, A. Stelmachowski, Polskie prawo rolne na tle ustawodawstwa Unii Europejskiej, Wydawnictwa Prawnicze PWN, Warszawa 1999, s. 54.
} 
Mówiąc o rachunkowości rolnej, należy wskazać, jakich podmiotów ona dotyczy. Gospodarstwo rolne to podmiot rachunkowości, a definiuje się je jako podstawową jednostkę wytwórczą $w$ rolnictwie ${ }^{2}$. Można się również spotkać z definicją gospodarstwa, jako: „celowo zorganizowanego zespołu ludzi, ziemi i innych środków produkcji, którego zadaniem jest wytwarzanie produktów rolniczych przez uprawę roślin i chów zwierząt"”.

Gospodarstwo rolne dysponuje zatem klasycznymi czynnikami produkcji od wielu wieków. Jednak ich znaczenie zmienia się wraz z rozwojem myśli technicznej. W dzisiejszych czasach niezmiernie ważnym czynnikiem produkcji stała się organizacja, która to gwarantuje racjonalne kierowanie i zarządzanie poprzez podejmowanie decyzji dotyczących odpowiedniego łączenia pozostałych trzech czynników produkcji.

Reasumując, można uznać, że gospodarstwo rolne to podmiot, kttóry powinien posiadać odpowiednio zorganizowane zasoby składników gospodarczych. Cechować powinno się ono dobrą organizacją pracy, a prowadzący gospodarstwo rolne powinien być odpowiednio uzdolniony i wykształcony jako wytwórca produktów rolnych. Gospodarstwo rolne, jak każdy inny podmiot produkcyjny, gromadzi składniki materialne i niematerialne, ruchomości i nieruchomości w celu prowadzenia działalności. Dla rolnika, jako przedsiębiorcy, najważniejszym składnikiem majątku będzie grunt rolny, na którym odbywa się produkcja oraz wymiana dóbr i usług o charakterze rolnym ${ }^{4}$.

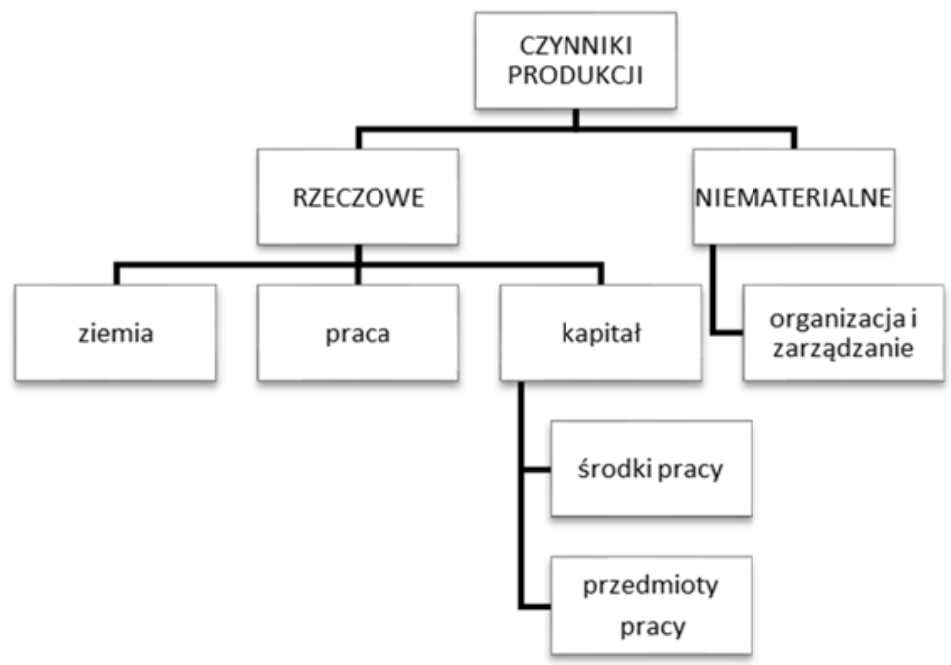

Źródło: opracowanie własne.

Rysunek 1. Czynniki produkcji w rolnictwie

\footnotetext{
${ }^{2}$ Ibidem, s. 77.

${ }^{3}$ Encyklopedia ekonomiczno-rolnicza, Warszawa 1964, s. 301.

${ }^{4}$ R. Budzinowski, Koncepcja gospodarstwa rolnego w prawie rolnym, Poznań 1992, s. 147.
} 
Specyfika sektora rolnego polega na tym, że rozwój rolnictwa nie nadąża za rozwojem pozostałych działów gospodarki. Akumulacja i reprodukcja rozszerzona $\mathrm{w}$ rolnictwie jest ograniczona ${ }^{5}$. Ziemia jako czynnik produkcji $\mathrm{w}$ rolnictwie jest bardzo osobliwa, a produkcja rolna jest specyficzna. Ziemia ma ograniczoną podaż, która jest nieelastyczna cenowo w krótkim okresie. Powiększenie zasobów ziemi przydatnej do uprawy jest niemożliwe. W dłuższym okresie można pozyskać nowe jej zasoby, poprzez odpowiednie zabiegi agrotechniczne. Powierzchnia gruntów jest globalnie stała, więc pozyskiwanie nowych zasobów ziemi $\mathrm{w}$ ten sposób jest ograniczone. Ziemia jest również niemobilna przestrzennie, co oznacza, że jest zupełnie związana z miejscem i nie można jej przenieść tam, gdzie można by ją wykorzystać w sposób bardziej efektywny. Czynnik ziemi nie podlega również zużyciu $\mathrm{w}$ procesie produkcji, z zastrzeżeniem zachowania dobrej kultury rolnej, co oznacza jej trwałość ${ }^{6}$.

Oprócz ziemi gospodarstwo dysponuje innymi zasobami. W sektorze rolnym działają mechanizmy rynkowe i pozarynkowe, jak w każdym innym i trzeba je zrozumieć. Rolnikom ciężko jest osiągać wysoką efektywność alokacji zasobów w sektorze rolnym. Mogą to osiągać poprzez ograniczanie cykliczności produkcji rolnej oraz stabilizacji cen. Można próbować tworzyć odpowiednie struktury hierarchiczne, które są pomocne w obniżaniu i stabilizacji marż. Marshallowskie okresy rynkowe w rolnictwie są wydłużone, a mobilność czynników produkcji sektora jest niska. Dokonuje się pewnych ingerencji w ramach sektora, jak np.: magazynowanie nadwyżek produkcyjnych, usprawnianie systemu informacji rynkowej oraz formy wymiany barterowej ${ }^{7}$.

\section{Sektor rolny w Polsce - rys historyczny od 1945 r. do chwili obecnej}

W okresie powojennym w Polsce rozpoczęło się kształtowanie mechanizmu centralnego planowania oraz zarządzania gospodarką. Do 1947 r. tworzone plany obejmowały krótkie odstępy czasu. Oczywiście, metody planowania były bardzo prymitywne, przy wsparciu ZSRR. Periodyzacja polityki rolnej PRL jest następująca ${ }^{8}$ :

- okres odbudowy w latach 1944-1948,

- okres kolektywizacji, przypadający na lata 1948-1956,

- ostatni przedział czasowy, zwany okresem socjalizacji pośredniej, datowany na lata 1956-1989.

${ }^{5}$ W. Czternasty, B. Czyżewski, Struktury kierowania agrobiznesem w Polsce, AE w Poznaniu, Poznań 2007, s. 46.

${ }^{6}$ Ibidem, s. 48.

${ }^{7}$ Ibidem, s. $128-131$.

${ }^{8}$ P. Czechowski, M. Korzycka-Iwanow, S. Prutis, A. Stelmachowski, Polskie prawo..., s. 39. 
Okres powojenny był burzliwy i trudny dla polskiej wsi. Dokonywano wtedy odbudowy oraz reform rolnych. Koniecznością było odtworzenie kraju po wojnie oraz wykształcenie nowych więzi ekonomicznych między wsią i miastem. Rozpoczęła się więc budowa gospodarki uspołecznionej. Reforma rolna miała na celu likwidację dużych prywatnych gospodarstw rolnych, powiększenie gospodarstw małorolnych oraz karłowatych. Tworzono również nowe gospodarstwa chłopom bezrolnym. Twórcy nowego ustroju chcieli w ten sposób zwiększyć swoje poparcie ze strony wsi ${ }^{9}$.

Głównym przedmiotem regulacji po wojnie stała się ziemia. Reforma rolna na podstawie dekretu PKWN z 6 września 1944 r. przeprowadzana była głównie metodami administracyjnymi. Podziałom poddano głównie mienie poniemieckie. W tym okresie trwała również akcja osadnictwa na Ziemiach Odzyskanych $^{10}$.

Niestety, ówczesna polityka rolna realizowana przez władze państwowe cechowała się brakiem konsekwencji w działaniu, co odbijała się na jakości i wydajności funkcjonowania sektora rolnego. Nowe władze rozpoczęły kolektywizację na wzór radziecki, co było sprzeczne z polską rzeczywistością. Przeciw kolektywizacji początkowo był W. Gomułka, natomiast za nią odpowiadał się B. Bierut. Od 1948 r. rozpoczęła się walka z kułakami, czyli zamożnymi, postępowymi chłopami. Działania te przyczyniły się do zdławienia oznak samodzielności i przedsiębiorczości polskiego rolnika. Lata powojenne to bardzo burzliwy i ciężki okres dla polskiej wsi, a zwłaszcza dla indywidualnego rolnika. Świadczą również o tym takie zdarzenia tego okresu jak: wypadki gryfickie, czyli wystąpienia zbuntowanych chłopów, którzy w tamtych czasach byli klasyfikowani według zamożności ${ }^{11}$. Rolnicy wzięli udział w pokazowym procesie ${ }^{12}$.

Sytuacja polskiej wsi zmieniła się w latach 1956-1970. W. Gomułka opowiedział się po stronie właścicieli gospodarstw indywidualnych. Był to okres rozwoju wielu spółdzielni. Również powierzchnia Państwowych Gospodarstw Rolnych uległa zmniejszeniu ${ }^{13}$. Nieco bardziej wspomożony został sektor indywidualny. Jednak po raz kolejny nie określono kierunku przyjętej polityki agrarnej. Nie zostały ustalone żadne plany działań długookresowych. Lata 19561958 były najlepsze dla polskiej wsi, ponieważ wtedy zwiększono kredytowanie gospodarstw indywidualnych oraz uelastyczniono zasady obrotu ziemią ${ }^{14}$.

${ }^{9}$ J. Skodlarski, Zarys historii gospodarczej Polski, Wydawnictwo Naukowe PWN, Warszawa-Lódź 2000, s. 371.

${ }^{10}$ P. Czechowski, M. Korzycka-Iwanow, S. Prutis, A. Stelmachowski, Polskie prawo..., s. 40.

${ }^{11}$ H. Minc na posiedzeniu VII Plenum KC PPR w 1948 r. przedstawił podział klasowy polskiej wsi, dzieląc rolników na biedniaków, średniaków i kułaków.

${ }^{12}$ C. Marzec, Bezpośrednie przyczyny i przebieg wydarzeń gryfickich w 1951 roku, [w:] K. Kozłowski (red.), Ziemia Gryficka 1945-1985, Gryfice 1987, s. 50, 56-58.

${ }^{13}$ J. Skodlarski, Zarys..., s. 442.

${ }^{14}$ Ibidem, s. 443. 
Ożywienie gospodarcze w latach 1971-1975 przyniosło dynamiczny rozwój produkcji przemysłowej. Rozwijała się motoryzacja oraz liczne obiekty przemysłowe jak np. Huta Katowice, Port Północny, kopalnie węgla itd. Przemysł przejął środki budżetowe, co spowodowało niedoinwestowanie rolnictwa. Polityka rolna stała się niestabilna i zmienna. Polska wpadła w pułapkę zadłużeniową, a po 1975 r. nastąpił czas załamania rynku artykułów spożywczych. Od 1978 r. załamaniu uległ cały proces inwestycyjny w Polsce. Gospodarka została przeinwestowana. Wieś weszła w fazę kryzysu. Spadła produkcja rolna. PGR i kółka rolnicze, mimo znacznych inwestycji i kapitału, osiągnęły gorsze wyniki gospodarcze od niedoinwestowanych gospodarstw indywidualnych ${ }^{15}$.

$\mathrm{Na}$ złą sytuację rolnictwa tego okresu składają się przede wszystkim patologie systemu nakazowo-rozdzielczego, który to $\mathrm{w}$ wyniku nieprzemyślanych decyzji, źle skalkulowanych lub podejmowanych pod presją społeczeństwa albo decydentów powodował znaczne marnotrawstwo rezerw, środków oraz pracy ludzkiej. Taki sposób gospodarowania powodował zwiększenie przepaści w poziomie technologicznym między Polską a krajami zachodnimi ${ }^{16}$.

Po 1990 r. w Polsce powrócił mechanizm wolnorynkowy. Gospodarka centralnie planowana upadła. System komunistyczny załamał się w Polsce i na świecie. Polska rozpoczęła podążanie w nowym kierunku na skutek zbliżenia się do Europy Zachodniej. Okres po 1990 r. to czas intensywnej reorganizacji państwa. Okres przebudowy sektorowej, a zwłaszcza sektora rolnego okazał się trudniejszy i bardziej kosztowny społecznie niż przewidywano. Zmiana systemu politycznego okazała się stosunkowo łatwiejsza ${ }^{17}$.

Rozpoczął się również okres przemian w rolnictwie. Uwarunkowania do przemian $\mathrm{w}$ tym sektorze były najgorsze, $\mathrm{w}$ porównaniu $\mathrm{z}$ innymi gałęziami gospodarki. Wpływ na ten fakt miała polityka rządu poprzedniego systemu, głównie ciągłe niedoinwestowanie sektora rolnego. W nowym systemie przemiana gospodarstw rolnych rozpoczęła się od stanu, w którym gospodarstwa były zacofane agrotechnicznie, ich struktura była nieprawidłowa, a wykształcenie rolników na niskim poziomie. Nowe rządy również nie przygotowały skutecznego programu naprawczego. Przebudowa systemu politycznego i gospodarczego w Polsce trwa już ponad 20 lat. Jednak wiele problemów wsi nie zostało rozwiązanych do tej pory. Najważniejszą zmianą po upadku komunizmu stało się wprowadzenie systemu rynkowego. Przyniosło to wiele korzystnych zmian dla gospodarki, jak np. ożywienie gospodarcze, jednak gospodarka poniosła też liczne konsekwencje, jak stagnacja i kryzys w wielu tradycyjnych

${ }^{15}$ Ibidem, s. 479.

${ }^{16}$ Ibidem, s. 530.

${ }^{17}$ T. Kisielewski, A. Wojtas (red.), Polska wieś na drodze do Unii Europejskiej, Wydawnictwo Akademii Bydgoskiej im. Kazimierza Wielkiego, Bydgoszcz 2004, s. 13. 
sektorach. Sektorem, który ucierpiał w sposób wyjątkowy to rolnictwo oraz wieś jako miejsce życia szczególnej grupy ludności.

Wieś reformuje się powolnie z uwagi na brak środków na inwestycje. Wyniki produkcyjne są niezadowalające. Sytuacja ludności wiejskiej w pierwszych latach transformacji stała się tragiczna. Masowa likwidacja PGR z dnia na dzień, wbrew rachunkom ekonomicznym spowodowała znaczne bezrobocie i zapaść wśród ludności wiejskiej. Duże gospodarstwa były likwidowane w ciągu cyklu produkcyjnego (po zasiewach, a przed zbiorami). Zmarnowano wiele z majątku, na który władze PRL poniosły spore nakłady. Maszyny i urządzenia zostały rozkradzione lub pozostały w likwidowanych gospodarstwach i wpływ czynników atmosferycznych spowodował ich zniszczenie. Podobna sytuacja miała miejsce $\mathrm{z}$ budynkami produkcyjnymi (oborami, chlewniami, warsztatami, paszarniami czy silosami). Nienależycie zabezpieczone, pozostawione bez ochrony i nadzoru zostały rozkradzione, zdewastowane bądź pochłonięte przez naturę.

Najważniejszą zmianą, jaka zaszła na wsi, jest wycofanie się państwa z jego opiekuńczej roli, co spowodowało wystawienie polskiego rolnictwa na konkurencję ze strony wysoko rozwiniętego rolnictwa zachodniego. Spowodowało to klęskę polskich rolników. Ich dochody w porównaniu z przemysłem były niższe nawet o $70 \%$. Konsekwencją tego były ogólny brak i zahamowanie inwestycji, a także ograniczenie zastosowania potrzebnych środków produkcyjnych.

Wejście Polski do Unii Europejskiej spowodowało konieczność realizacji Wspólnej Polityki Rolnej. Modernizacja polskiego rolnictwa jest realizowana właśnie w oparciu o jej założenia. Polskich rolników objęły mechanizmy funkcjonujące w Unii Europejskiej. Rolnicy stali się beneficjentami płatności bezpośrednich oraz innych programów dopłat dla rolników. Prawo unijne określa dokładnie, co można wspierać ze środków publicznych. Ważne stało się umocnienie pozycji rolników na rynku produktów rolnych. Unia Europejska wspiera grupy producentów rolnych, usługi doradcze, finansowe oraz zarządcze na rzecz rolników. Co ważne, renesans swój ma w obecnej chwili spółdzielczość rolnicza. Oczywiście w chwili obecnej ma ona charakter dobrowolny, nieprzymusowy. Rolnicy sami stają się inicjatorami tworzenia spółdzielni, a nie tak jak w okresie PRL, państwo.

Dzięki akcesji Polski do Unii Europejskiej można zaobserwować znaczny postęp cywilizacyjny, oczywiście do tej pory pozostaje zróżnicowanie regionalne. Nadal jednak wydajność gospodarstwa rolnego jest mniejsza niż innych działów gospodarki narodowej. Zmiany te powodują wdrażanie kolejnych niezbędnych rozwiązań dostosowawczych. Powoli konieczne stało się wprowadzenie ewidencji księgowej w gospodarstwach rolnych. Rachunkowość w rolnictwie staje się rzeczywistością. 


\section{Rachunkowość w rolnictwie - przymus czy konieczność?}

Sektor rolny, jak już wcześniej wspomniano, jest specyficznym działem gospodarki narodowej. Dane na temat funkcjonowania gospodarstw rolnych rolników indywidualnych w dużej mierze pochodzą z powszechnych spisów rolnych oraz badań reprezentacyjnych przeprowadzanych regularnie przez GUS. Niestety badania te mają charakter szacunkowy, a decyzje podejmowane na podstawie ich wyników mogą być niekorzystne dla wielu rolników ${ }^{18}$.

Prace nad regulacjami dotyczącymi prowadzenia rachunkowości przez rolników trwają od wielu lat. Gospodarka wskazuje na konieczność prowadzenia pewnej formy ewidencji zdarzeń gospodarczych w gospodarstwach rolnych. GUS nie ma obowiązku formalnego do prowadzenia sprawozdawczości związanej z wynikami gospodarstw rolnych. Co zatem dyktuje konieczność wprowadzenia ewidencji w gospodarstwie? Nie da się ukryć, że głównie użyteczność tej ewidencji w zarządzaniu gospodarstwem rolnym, tak jak każdym innym przedsiębiorstwem, $\mathrm{z}$ tym że to przedsiębiorstwo jest wyjątkowe pod względem procesu produkcji oraz samego produktu finalnego.

Współczesny rolnik musi przecież realizować w pełni wszystkie funkcje zarządzania zdefiniowane przez Henriego Fayola ${ }^{19}$ :

- planowanie,

- organizowanie,

- prowadzenie (kierowanie ludźmi, motywowanie),

- kontrolowanie.

Współczesny rolnik podlega regułom rynku (konkuruje z innymi rolnikami i przedsiębiorstwami rolnymi z kraju i całego świata). Musi on ustalić cel końcowy w ramach planowania oraz dostosować gospodarstwo do otaczającej rzeczywistości. Cele pośrednie ustalane powinny być nieustannie. Planować można tylko w oparciu o znaną rzeczywistość. Niewątpliwe jest to, że odpowiednio zagregowane dane finansowe pozwalają w pewnym zakresie na podniesienie skuteczności planowania.

Dzisiejszy rolnik musi być dobrym organizatorem. Zarządza on bowiem specyficznym warsztatem pracy, jakim jest gospodarstwo rolne. Tu ważne jest określenie sekwencji działań mających doprowadzić do uprzednio założonych celów. Jak więc prawidłowo tworzyć inwestycje lub łączyć zasoby rzeczowe i osobowe, bez dobrej znajomości posiadanych zasobów?

Przy prowadzeniu gospodarstwa rolnego należy pamiętać również o odpowiednim motywowaniu, czyli wywoływaniu w kimś stanu gotowości lub chęci

${ }^{18}$ S. Goraj, S. Mańko, R. Sass, Z. Wyszkowska, Rachunkowość rolnicza, Difin, Warszawa 2004, s. 12-21.

${ }^{19}$ I. Durlik, Inżynieria zarządzania. Strategia i projektowanie systemów produkcyjnych, Placet, Warszawa 1995, s. 259. 
do wykonywania określonych działań. Przedsiębiorca rolny (rolnik) musi zmotywować pracowników najemnych, ale również zmotywować należy członków rodziny współtworzących gospodarstwo rolne, czyli któryś z członków rodziny musi przejąć inicjatywę w gospodarstwie w taki sposób, aby pozostali widzieli $\mathrm{z}$ tego płynące korzyści.

Kontrolowanie nie jest również bez znaczenia w rolnictwie. Polega ono na porównaniu stanu faktycznego z założeniami, które były punktem wyjścia. Dokonuje się analizy odchyleń od założeń oraz wyciąga stosowne wnioski. Definicja brzmi bardzo poważnie, ale w gospodarz kontroluje codziennie wiele elementów procesu produkcji, nawet nie zdając sobie sprawy, że realizuje jedną z funkcji zarządzania. Kontrolowanie w gospodarstwie to choćby porównanie sprzedanej ilości mleka z zakontraktowaną, kontrola upraw i ich stanu, w celu zgłoszenia odchyleń wynikających choćby z zmian wywołanych czynnikami atmosferycznymi do ARiMR, w celu korekty wniosku o płatności obszarowe.

Pamiętać należy, że dane liczbowe dostarczone w ramach systemu rachunkowego w gospodarstwie rolnym nie mogą być zbyt rozbudowane i skomplikowane. Należy opracować taki system, aby był użyteczny dla danego gospodarstwa, przy uwzględnieniu jego areału, wielkości czy wreszcie specyfiki produkcji.

Jeśli księgi rachunkowe mają być obowiązkiem dla rolnika, to należy zastanowić się dla kogo i na jakich zasadach. W UE planowane jest objęcie obowiązkową ewidencją księgową wszystkich rolników, którzy korzystają z dopłat. Osobiście uważam, iż jest to zbyt szeroka grupa. Warto bowiem pamiętać, że z dopłat korzystają również gospodarstwa o powierzchni np. 2 ha użytków rolnych, a o generowaniu znaczących dochodów z działalności rolnej nie można tutaj w ogóle mówić, o ile nie są to specjalne rodzaje upraw.

Objęcie rolników obowiązkiem opłacania podatku dochodowego pociągnie za sobą konieczność ustalenia dochodu, czyli ewidencji przychodów i kosztów, nawet w najprostszy sposób. W krajach Europy Zachodniej już od dawna rolnicy prowadzą rachunkowość (np. w Danii). Ewidencja przez nich prowadzona jest prosta, obejmuje przychody i koszty.

W przypadku niewielkich gospodarstw prostota jest zaletą, jednak w dużych bardziej rozbudowana księgowość może przynieść dodatkowe korzyści, wynikające choćby z możliwości dokonania kalkulacji. Nie należy wprowadzać zmian w sposób szokowy, ponieważ wielu rolników nigdy nie korzystało z żadnej formy ewidencji, a wypełnianie wniosków do ARiMR jest już dość skomplikowane dla nich. Pewne jest, że wielu rolników zostanie zmuszonych do korzystania z pomocy firm świadczących usługi księgowe.

Niepokojące jest to, że niewiele firm zajmuje się rachunkowością rolną i zdaje sobie świadomość z konieczności jej poznania i wprowadzenia. Zastąpienie podatku rolnego podatkiem dochodowym spowoduje konieczność prowadzenia księgi przychodów i rozchodów lub pełnej księgowości przez rolników. 
Do chwili obecnej nie ma jednoznacznie określonych progów granicznych do prowadzenia ewidencji. Szacuje się, że gospodarstwa rolne osiągające przychód na poziomie 4-5 mln zł będą zobowiązane do prowadzenia ksiąg rachunkowych, a pozostałe będą mogły dokonać wyboru ${ }^{20}$.

Dla firm specjalizujących się w usługach księgowych jest to bez wątpienia dobra okazja do pozyskania nowych klientów. Rynek jest nasycony biurami rachunkowymi, ale wzrost popytu na usługi księgowe może spowodować wzrost cen. Gospodarstwa wielkoobszarowe będą z pewnością musiały rozważyć konieczność zatrudnienia osoby z odpowiednimi kwalifikacjami do prowadzenia księgowości.

Nawet najprostsza ewidencja wymaga pewnych umiejętności. Nie wszyscy rolnicy je posiadają, więc widać również konieczność przeprowadzania szkoleń w obszarach wiejskich z zakresu ewidencji księgowej. Narzucenie księgowości ma charakter odgórny, wiec kto powinien ponosić koszty organizacji takowych kursów?

W tym miejscu należy przytoczyć orzeczenie NSA dotyczące limitów przychodów związanych z koniecznością prowadzenia ksiąg rachunkowych przez rolników ${ }^{21}$ : „W stanie prawnym obowiązującym od dnia 1 stycznia $2001 \mathrm{r}$. obowiązek prowadzenia ksiąg rachunkowych, o których mowa w art. 24a ust. 1 i ust. 4 ustawy z dnia 26 lipca 1991 r. o podatku dochodowym od osób fizycznych (Dz.U. 2000, nr 14, poz. 176 ze zm.) nie dotyczy podatników uzyskujących przychody z działów specjalnych produkcji rolnej (art. 2 ust. 1 pkt 1 i ust. 3), bez względu na wielkość tych przychodów, o ile podatnicy ci nie zgłosili zamiaru prowadzenia ksiąg w trybie określonym w art. 24a ust. 2 pkt 2 i art. 15 zdanie drugie tej ustawy".

Ustrój gospodarczy uległ przekształceniom w sposób znaczący po roku 1989. Dla rolników przyniosło to szereg zmian. Przystąpienie Polski do Unii Europejskiej powoduje konieczność ciągłych zmian dostosowawczych. Gospodarstwo funkcjonuje na zasadach rynkowych. Rolnik, który chce nim prawidłowo zarządzać, musi pojąć ograniczenia i zasady funkcjonowania gospodarstwa rolnego. Dziś, jak już wcześniej wspomniano, rolnik powinien opanować umiejętność sporządzania planów krótko- i długoterminowych. Współczesny rolnik powinien umieć prowadzić właściwą ewidencję księgową, która zapewni kontrolę realizacji planów. W końcu konieczne jest stałe monitorowanie stanu gospodarstwa. Do sprawnego zarządzania konieczne jest dysponowanie sporą ilością informacji. Koniecznością jest kontrolowanie jakości danych, jakie są rejestrowane w trakcie prowadzenia rachunkowości, bo od nich zależą efekty zarządza-

${ }^{20} \mathrm{http}: / /$ www.ppr.pl/artykul-rolnicy-zaloza-ksiegi-rachunkowe-165647-dzial-17.php (dostęp 13.05.2013).

${ }^{21}$ II FPS 2/10 - Uchwała NSA, Publikacja w u.z.o. ONSAiWSA 2011, nr 2, poz. 25. 
nia gospodarstwem. Rachunkowość wspomaga ludzką pamięć przy kontrolowaniu i planowaniu 22 .

Do chwili obecnej do prowadzenia rachunkowości zobligowane są gospodarstwa, które posiadają osobowość prawną. W 1996 r. konieczność prowadzenia rachunkowości została nałożona na gospodarstwa, które skorzystały z kredytów subwencjonowanych przez ARiMR $^{23}$ W ramach wsparcia dla „młodych rolników" - urządzenie i modernizacja gospodarstwa rolnego. Obowiązek taki ciążył na rolniku przez cały okres spłacania kredytu ${ }^{24}$. System rachunkowości rolnej w Polsce został wdrożony przez IERiGŻ i stał się jedynym funkcjonującym w 1996 r. w skali ogólnopolskiej. Zastosowano w nim jednolity sposób gromadzenia danych źródłowych, na podstawie których obliczono standardowe wyniki działalności indywidualnych gospodarstw rolnych ${ }^{25}$.

Nadal jednak nasuwa się pytanie, jaka będzie granica, od której rolnicy będą zobowiązani do płacenia podatku dochodowego, a do której mogą pozostać przy podatku rolnym? Wiele kwestii do tej pory jest nieuregulowanych. W propozycjach progów pojawia się powierzchnia 5 lub 6 ha. W tym miejscu należy zadać pytanie, czy jest to powierzchnia ewidencyjna gruntów, czy przeliczeniowa? Jeśli ewidencyjna, to rolnicy gospodarujący na ziemiach klasy V i VI są skazani na dodatkowe koszty, a gospodarstwa te niestety mogą nie być w stanie pokryć kosztów usług księgowych. W sprawozdaniu finansowym, w bilansie występuje produkcja w toku i produkcja niezakończona. Na koniec roku konieczne jest sporządzenie remanentu. W jaki sposób dokonać go przy np. uprawach? Wszak jesienią rolnicy przygotowują pola na kolejny rok. A inwentarz żywy to też produkcja.

Nadmienię w tym miejscu nieco o zmianach w zakresie podatku rolnego, ponieważ Sejm dokonał nowelizacji ustawy o podatku rolnym. Obliczany on będzie według średniej ceny skupu żyta za 11 kwartałów poprzedzających rok podatkowy. W chwili obecnej podatek wyliczany jest na podstawie trzech pierwszych kwartałów roku poprzedzającego. Zabieg ten ma na celu zniwelowanie wahań cen rynkowych na rynku zbóż. Pierwsze czytanie projektu zmian odbyło się 17 lutego 2012 r., natomiast drugie na posiedzeniu Sejmu 3 kwietnia 2013 r. Metoda obliczania podatku się nie zmieni. Będzie to nadal równowartość 2,5 q żyta od 1 ha przeliczeniowego ${ }^{26}$.

Same przepisy są niejednoznaczne, jeśli chodzi o definicję gospodarstwa rolnego (istnieje ich ponad 10) oraz definicję działalności rolniczej i rolnika (co

\footnotetext{
${ }^{22} \mathrm{http}$ ://www.wodr.poznan.pl/index.php?option=com_k2\&view=item\&id=2361:rachunkowo $\% \mathrm{C} 5 \% 9 \mathrm{~B} \% \mathrm{C} 4 \% 87$-w-gospodarstwie-rolnym\&Itemid=704 (dostęp 13.05.2013).

${ }^{23}$ Agencja Restrukturyzacji i Modernizacji Rolnictwa.

${ }^{24}$ Rozporządzenie Rady Ministrów z 04.04.1995 r. (Dz.U., nr 47 z 09.05.1995 r., poz. 244).

${ }^{25}$ S. Goraj, S. Mańko, R. Sass R., Z. Wyszkowska, Rachunkowość..., s. 13.

26 http: //ksiegowosc.infor.pl/wiadomosci/140490,Podatek-rolny--zmiana-zasad-obliczania.html (dostęp 14.05.2013).
} 
najmniej 5). Również przytoczony wcześniej wyrok NSA może być mylący, ponieważ NSA odnosił się do ksiąg określonych w art. 24a ust. 1 i ust. 4 ustawy o podatku dochodowym od osób fizycznych. Zdaniem ekspertów uchwała ta dotyczy aspektów podatkowych, zawężona została również do działów specjalnych produkcji rolnej, a nie odwołuje się do przepisów ustawy o rachunkowości. Zdaniem ekspertów rolnicy muszą prowadzić księgi rachunkowe zgodnie z ustawą, o ile ich przychody przekroczyły podane tam progi. Ustawa o rachunkowości wymienia jednostki, które są obowiązane do prowadzenia ksiąg rachunkowych wskazując formę prawną jednostki gospodarczej i wielkość przychodów, a nie przedmiot jej działalności ${ }^{27}$.

Rolnicy opodatkowani podatkiem rolnym nie muszą ustalać podstawy do opodatkowania w sposób klasyczny, ponieważ mechanizm naliczania podatku rolnego jest zupełnie inny, niż podatku dochodowego ${ }^{28}$. Dane dotyczące wielkości przychodów i ponoszonych kosztów (dane księgowe) nie są więc niezbędne dla rolnika. Mogą one jednak ułatwić efektywne, zgodne z rachunkiem ekonomicznym zarządzanie.

Czy wprowadzenie rachunkowości w gospodarstwach na szeroką skalę będzie korzystne dla rolników? Zdania są podzielone. W chwili obecnej dane na temat dochodu gospodarstw rolnych ustalane są przez GUS. Wielu rolników uważa, że wprowadzenie ewidencji przychodów i kosztów jako obowiązkowej spowoduje, że dochody wyliczane dla gospodarstw rolnych będą urzeczywistnione, a przede wszystkim znacznie niższe. Obecnie dochód z pracy $\mathrm{w}$ indywidualnych gospodarstwach rolnych z 1 ha przeliczeniowego wynosi $2713 \mathrm{zt}^{29}$. Taka wielkość brana jest pod uwagę, gdy rolnik stara się o świadczenia społeczne, stypendia lub inne formy wsparcia. Do ustalenia świadczeń z pomocy społecznej zatem brany jest dochód daleki od faktycznego. Na skutek takiego obliczania, a raczej szacowania dochodu rolniczego wiele rodzin nie otrzymuje należnych im zasiłków. Wprowadzenie rachunkowości może więc problem dochodowości ostatecznie rozwiązać, podnosi się jednak problem zatrudniania księgowych, ponieważ wielu rolników nie będzie stać na ponoszenie takich kosztów.

Unia Europejska zmierza w kierunku prowadzenia księgowości w gospodarstwach rolnych. Na pewno opodatkowanie w postaci podatku rolnego, które jest niezależne od wielkości zbiorów $\mathrm{w}$ danym roku jest niesprawiedliwe. Natomiast przy urodzaju państwo traci na tej formie obliczania wielkości obciążenia podatkowego. Opodatkowanie gospodarstwa podatkiem dochodowym niweluje skutki nieurodzaju w przypadku obciążenia podatkowego.

${ }^{27}$ Ustawa o rachunkowości, art. 2 ust. 1 (Dz.U. 2009, nr 152, poz. 1223 z późn. zm).

${ }^{28}$ Ibidem.

${ }^{29}$ Obwieszczenie Prezesa GUS z 21 września 2012 r. w sprawie wysokości przeciętnego dochodu z pracy w indywidualnych gospodarstwach rolnych z 1 ha przeliczeniowego w $2011 \mathrm{r}$. 
Podatek dochodowy dla rolników wprowadzony zostanie w roku 2014. Docelowo nie będzie dodatkowym obciążeniem dla rolnika, bo zastąpi podatek rolny. Urealnienie dochodów wydaje się więc być lepszym rozwiązaniem dla właściciela gospodarstwa rolnego. Objęcie rolników podatkiem dochodowym to również likwidacja pewnego ,przywileju”, jakim był podatek rolny. Urealnienie dochodów może spowodować korzyści dla rolników w postaci zwiększenia świadczeń społecznych wypłacanych rzeczywiście najbiedniejszym. Warto wspomnieć, że podatek ma być neutralny dla budżetu państwa (wpływy nadal mają być przekazywane do gmin) i dla rolników ${ }^{30}$.

Ocenia się, że podatek dochodowy to dobre rozwiązanie dla rolnika, bo zostanie opodatkowany jego rzeczywisty dochód, a nie dochód szacowany na podstawie powierzchni przeliczeniowej gospodarstwa. Takie zmiany spowodują opodatkowanie rzeczywistej efektywności produkcji, której miarą jest dochód. Ujednolicenie systemu podatkowego dla wszystkich grup społecznych powoduje wzrost postrzegania sprawiedliwości podatkowej. Samo objęcie rolników systemem rachunkowości może powodować $\mathrm{w}$ przyszłości debatę $\mathrm{w}$ kwestii objęcia rolników systemem ubezpieczeń społecznych ZUS. Zasady objęcia podatkiem dochodowym wydają się wiec nie być krzywdzące dla rolników. Mają być nim objęte tylko większe gospodarstwa rolne (powyżej 6 ha). Okres przejściowy ma wynosić dwa lata od momentu wprowadzenia zmian. Przewidziano również szkolenia dla rolników ${ }^{31}$.

Polska gospodarka integruje się z gospodarką zachodnioeuropejską. Polska zyska dzięki temu wiele możliwości, ale i polscy rolnicy staną przed nowymi wyzwaniami. Wspólna Polityka Rolna jest trudna do prowadzenia i niestety nadal widać zróżnicowanie w strukturze oraz poziomie dochodów poszczególnych regionów ${ }^{32}$.

Zmiany gospodarcze wymagają, aby producenci rolni rzetelnie gromadzili informacje na temat ich sytuacji ekonomicznej i produkcyjnej. Prowadzenie rachunkowości zapewnia realizowanie tych postulatów, niemniej jednak system rachunkowości rolnej, z uwagi na specyfikę tej działalności, musi być do niej dostosowany. Ustawa o rachunkowości z 29 września 1994 r. uregulowała problematykę dostosowywania rachunkowości w Polsce do standardów unijnych i międzynarodowych. Dotyczy ona także obszaru rolnictwa. Jak już wspomniano wcześniej, rolnicy korzystający z kredytów subwencjonowanych przez ARiMR musieli prowadzić księgi rachunkowe.

${ }^{30} \mathrm{http} / / /$ podatki.onet.pl/for-popiera-rachunkowosc-dla-rolnikow-krok-w-dobry,19925,5264995, agencyjne-detal (dostęp 14.05.2013).

${ }^{31} \mathrm{http}$ ://podatki.onet.pl/for-popiera-rachunkowosc-dla-rolnikow-krok-w-dobry,19925,5264995, agencyjne-detal (dostęp 14.05.2013).

${ }^{32}$ Wspótczesne uwarunkowania organizacji produkcji $w$ gospodarstwach rolnych, Instytut Uprawy, Nawożenia i Gleboznawstwa, Państwowy Instytut Badawczy, z. 7, Puławy 2007, s. 55. 
Dziś można śmiało powiedzieć, że każde gospodarstwo rolne, które ma konkurować na rynku oraz rozwijać się i korzystać z różnorakich form wsparcia z budżetów krajowych i UE, powinno prowadzić księgi rachunkowe. Umożliwi to urzędom odpowiednią kontrolę wydatkowania tych środków, ale również pozwoli rolnikowi na prowadzenie rachunku ekonomicznego.

\section{Zakończenie}

Wprowadzenie systemu ewidencji przychodów i kosztów w gospodarstwach rolnych stanie się w niedalekiej przyszłości „gorącym” tematem. Niewątpliwie zmiany są konieczne dla sektora rolnego, jednak należy wprowadzać je w sposób przemyślany oraz stopniowo.

Polskie rolnictwo od dziesiątek lat boryka się z brakiem konsekwencji przy realizowaniu polityki rolnej. Okres powojenny był huśtawką polityczną dla rolnika indywidualnego, ciężkim okresem, w którym gospodarowanie w oparciu o rachunek ekonomiczny było bardzo trudne, a wręcz niemożliwe.

Również transformacja ustrojowa przyniosła gwałtowne i nieoczekiwane zmiany dla polskiej wsi. PGR zostały zlikwidowane z dnia na dzień generując ogromne masy bezrobotnych na wsiach. Takie posunięcie spowodowało powstanie wielu innych problemów i patologii na polskiej wsi (dewastacja mienia po PGR, długotrwałe bezrobocie, patologie społeczne, takie jak alkoholizm, przemoc itd.). Przystąpienie Polski do UE spowodowało dostęp do nowych środków finansowych dla rolników. Unia prowadzi również stabilną politykę rolną, którą musi realizować również Polska. Pomaga ona w rozwoju polskiej wsi, która $\mathrm{z}$ uwagi na uwarunkowania historyczne jest zacofana w porównaniu z krajami Zachodu.

Wprowadzenie podatku dochodowego dla rolników oraz obowiązkowego stosowania prostego systemu ewidencji przychodów i kosztów dla mniejszych gospodarstw, a pełnej księgowości dla dużych jest dobrym rozwiązaniem. Odpowiedzialni za wprowadzanie tych zmian powinni pamiętać o konsekwencji i ostrożności w realizowaniu tych założeń. Rachunkowość to dobre narzędzie do gromadzenia danych finansowych, które mogą być pomocne rolnikowi w wielu dziedzinach jego życia (bieżącym zarządzaniu gospodarstwem, planowaniu czy też ubieganiu się o kredyty lub świadczenia społeczne).

Podmioty zajmujące się świadczeniem usług księgowych powinny bacznie śledzić zmiany zachodzące w przepisach, ponieważ dla nich gospodarstwa staną się nowymi, specyficznymi klientami. 


\section{Literatura}

Budzinowski R., Koncepcja gospodarstwa rolnego w prawie rolnym, Poznań 1992.

Czechowski P., Korzycka-Iwanow M., Prutis S., Stelmachowski A., Polskie prawo rolne na tle ustawodawstwa Unii Europejskiej, Wydawnictwa Prawnicze PWN, Warszawa 1999.

Goraj S., Mańko S., Sass R., Wyszkowska Z., Rachunkowość rolnicza, Difin, Warszawa 2004.

Czternasty W., Czyżewski B., Struktury kierowania agrobiznesem $w$ Polsce, AE w Poznaniu, Poznań 2007.

Durlik I., Inżynieria zarządzania. Strategia i projektowanie systemów produkcyjnych, Placet, Warszawa 1995.

Dziedzic B., Minister rolnictwa zapowiada: Rolnicy zapłaca podatek dochodowy, „Polska Times”, 14.08.2012.

Encyklopedia ekonomiczno-rolnicza, Warszawa 1964.

Kisielewski, Wojtas A. (red.), Polska wieś na drodze do Unii Europejskiej, Wydawnictwo Akademii Bydgoskiej im. Kazimierza Wielkiego, Bydgoszcz 2004.

Marzec C., Bezpośrednie przyczyny i przebieg wydarzeń gryfickich w 1951 roku [w]: K. Kozłowski (red.), Ziemia Gryficka 1945-1985, Gryfice 1987.

Skodlarski J., Zarys historii gospodarczej Polski, Wydawnictwo Naukowe PWN, Warszawa-Lódź 2000.

Wspótczesne uwarunkowania organizacji produkcji w gospodarstwach rolnych, Instytut Uprawy, Nawożenia i Gleboznawstwa, Państwowy Instytut Badawczy, z. 7, Puławy 2007.

http://www.wodr.poznan.pl.

http://www.ppr.pl/artykul-rolnicy-zaloza-ksiegi-rachunkowe-165647-dzial-17.php.

http://www.rolnictwo-agro.pl/1671,0,rachunkowosc-w-rolnictwie-czy-pomoze-rolnikom.html.

http://podatki.onet.pl/for-popiera-rachunkowosc-dla-rolnikow-krok-w-dobry,19925,5264995, agencyjne-detal.

http://www.farmer.pl/finanse/podatki-rachunkowosc/zasady-rachunkowosci-rolnej,36680.html.

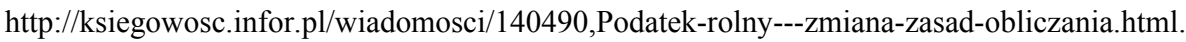
http://www.wodr.poznan.pl/index.php?option=com_k2\&view=item\&id=2301 :jaki-podatekdochodowy-w-rolnictwie?\&Itemid=707.

http://biznes.interia.pl/podatki/news/rolnicy-maja-placic-podatek-inwestycje-beda-bardziej, 1832228,4211 .

http://natemat.pl/27139,koniec-niesprawiedliwych-podatkow-rolnicy-zaplaca-tak-jak-wszyscyskok-na-wiecej-kasy-w-budzecie.

http://podatki.gazetaprawna.pl/artykuly/615665,rolnicy_nie_prowadza_ksiag_rachunkowych.html. http://wyborcza.biz/finanse/1,105684,12336783,Kalemba_podatek_dochodowy_w_rolnictwie_w _2014_roku.html.

\section{Streszczenie}

Artykuł jest poświęcony rachunkowości rolnej. Rolnictwo jest specyficznym i nieodzownym sektorem każdej gospodarki. W jej skład wchodzą przedsiębiorstwa wytwarzające produkty rolne pochodzenia roślinnego i zwierzęcego, a także świadczące usługi rolnicze. Co więcej, gospodarstwo rolne jest w wielu przypadkach głównym miejscem zatrudnienia całej rodziny rolnika, która przede wszystkim utrzymuje się z działalności rolniczej w swojej lokalnej społeczności. 
Z dniem wejścia w życie Traktatu o przystąpieniu Polski do Unii Europejskiej, który ustanawia wspólne zasady dla systemów wsparcia bezpośredniego w ramach wspólnej polityki rolnej, dostęp do różnego rodzaju instrumentów wsparcia dla rolnictwa umożliwił wprowadzenie wielu zmian. Rolnicy coraz powszechniej z nich korzystają.

Opracowanie to zawiera krótkie opisy specyfiki sektora rolnego oraz historii gospodarczej i politycznej polskiej wsi po 1945 roku. W ostatniej części opisano proponowane zmiany związane z zastąpieniem podatku rolnego, podatkiem dochodowym. Całość kończy podsumowanie, które ma na celu uzasadnienie konieczności prowadzenia księgowości przez rolników.

\section{Summary}

\section{INCOME TAX IN AGRICULTURE AND ACCOUNTS-THE SPECTRUM OF CHANGES FOR THE POLISH FARMER}

The article focuses on agricultural accounting. Agriculture is a specific and indispensable sector of each economy. It consists of businesses active in the production of agricultural products, both plant and livestock, as well as agricultural services. Furthermore, an agricultural holding, in many cases provides the main place of employment for farmer's family, who mainly make a living in their home localities taking agricultural activity.

With the entry into force of the Treaty concerning the accession of Poland, which establishes common rules for direct support schemes under the common agricultural policy and certain support schemes for farmers, the access to all sorts of financial and advisory instruments allowed agriculture to be changed. Farmers take advantage of such support more and more frequently.

This study presents brief descriptions of the characteristics of the agricultural sector, and the economic and political. history of the Polish village after 1945. The last part presents the proposed changes related to the replacement of the agricultural tax by the income tax. The work ends with a summary which aims to provide justification for the necessity of keeping accounts by farmers. 